\title{
RPS6KB2 Gene
}

National Cancer Institute

\section{Source}

National Cancer Institute. RPS6KB2 Gene. NCI Thesaurus. Code C24754.

This gene is involved in the regulation of cell growth and proliferation. 